\title{
TECHNICAL EFFICIENCY OF IRISH POTATO PRODUCTION: A CASE STUDY FROM NIGERIA
}

\author{
Dominic Midawa GULAK*, Ogheneruemu OBI-EGBEDI (it)
}

\author{
Address: \\ Department of Agricultural Economics, University of Ibadan, Ibadan 90001, Oyo State, Nigeria \\ *Corresponding author: dominicmidawa@gmail.com
}

\begin{abstract}
Research background: Irish-potato (Solanum tuberosum L.) is one of the main root crops in Nigeria with the potential to improve food security, income and human nutrition. However, farmers are losing outputs due to inefficiency in resource use, whereas, past studies on Irish potato in Nigeria have not focussed on efficiency of the enterprise.

Purpose of the article: This study is aimed at measuring technical efficiency to provide a way of quantifying and comparing the performance of each farmer, and identification of factors responsible for variation in technical efficiency. Hence, technical efficiency, and its determinants and returns to scale of Irish-potato farmers were analysed

Methods: Primary data was collected from 260 Irish potato farmers using a structured questionnaire through a multistage sampling method. Descriptive statistics (frequency, mean, standard deviation and percentages) and a two-stage estimation procedure to fit the stochastic frontier production function for Irish potato farmers were used.

Findings \& value added: Results indicated that the farmers have a mean age of 48 years which indicates an agile workforce. Over $80 \%$ of the farmers possessed some form of formal education, predominantly at the secondary level. The efficiency estimates indicated a disparity in technical efficiency among farmers with a mean technical efficiency of $89 \pm 4 \%$. The farmers were producing at decreasing returns to scale. At the same time, socio-economic factors of gender, extension contact, membership in cooperative society and farming experience were positive determinants of farmers' technical efficiency, while household size was negative. Thus, being a male farmer, farming experience, encouraging contact between farmers and extension workers as well as membership in cooperative societies, while reducing household size can improve technical efficiency in Irish potato production.
\end{abstract}

Key words: Irish potato; farmers; technical efficiency; returns to scale, SFA JEL Codes: C21; D22; D61; Q12

\section{INTRODUCTION}

Irish potato (Solanum tuberosum L.) is the greatest contributor of food energy in the developing regions of the world, providing 75 percent in food energy per unit area of the countries while both wheat and rice are capturing 58 percent of the total share in food energy (FAO, 2017; Sher et al., 2016). Global output is estimated at 388 million metric tonnes and the yield per hectare stands at 20,110.8kg/ha (FAOSTAT, 2019a). Developing countries produce over half of the world's output with China having the highest production in the world $(99,205,600$ metric tonnes in 2017), and almost one-third of the world's output is harvested in China and India (FAOSTAT, 2019a). Global domestic consumption rate of fresh and processed Irish potato stands at 34.64 kg/capita (FAOSTAT, 2016). In Africa, Irish potato production is estimated at 25 million metric tonnes with a yield of $13,215.4 \mathrm{~kg} / \mathrm{ha}$ (FAOSTAT, 2019a), and a consumption rate (fresh and processed) of 18.76 $\mathrm{kg} /$ capita/year in 2011 (FAOSTAT, 2016). In subSaharan Africa, Irish potato has had an average growth in demand of $3.1 \%$ and rank as the number one staple, particularly in East Africa (Wassihun et al, 2019). Nigeria is the seventh-largest producer in Africa, with an output of $1,284,370$ metric tonnes and a yield of $37,201 \mathrm{hg} / \mathrm{ha}$ $(3,720.1 \mathrm{~kg} / \mathrm{ha})$ in 2017 (FAOSTAT, 2019a). Domestic consumption of both fresh and processed Irish potato stands at $4.63 \mathrm{~kg} / \mathrm{capita}$ (FAOSTAT, 2016). Potato is critical to food security and sustenance of livelihoods of subsistent farmers, especially in the highlands areas where its growth can be economically sustained (Amadi, et al; 2021). The crop is mainly cultivated in commercial quantities in Plateau, Kaduna and Taraba states (Dimlong, 2012).

Irish potato is an underexploited food crop in Nigeria, despite its wide cultivation in commercial quantities (Muhammad et al., 2016) and potential to improve food security, income and human nutrition (SchulteGeldermann 2013). Several efforts have been devoted to the development and transfer of new technologies to improve Irish potato production in Nigeria; including Irish potato seed multiplication, training of farmers, Irish potato research, breeding and selection of new improved 
varieties (Zemba et al., 2013). However, annual Irish potato production in Nigeria has not improved appreciably (Jwanya et al., 2014; FAOSTAT, 2019b). This indicates that technological advances generated through research and investments have not widely translated into improved efficiency.

Previous research on Irish potato focused on agronomic practices, marketing efficiency, growth and crop productivity (Okonkwo et al., 2009; Wuyep et al., 2013; Zemba et al., 2013; Sanusi et al., 2017). Growth in output is not determined by introducing new technology alone, but by the efficiency with which technologies and inputs are used (Jwanya et al., 2014). Most resources used in agricultural production are not used at optimal levels and are constantly degraded (Panwall, 2018). These differences in technical efficiency level among farmers arise due to inefficiencies linked to farmers' and farms' specific characteristics (Wubshet, 2018). Irish potato farmers are losing yield due to inefficiency in resource use, and attaining high technical efficiency remains a problem among Irish potato farmers (Kiptoo et al., 2016). Hence, there is a knowledge gap on technical efficiency in Irish potato production and factors determining technical efficiency in Nigeria (Sanusi \& Babatunde, 2017). This study was undertaken to investigate the technical efficiency of Irish potato farmers, the response of output to inputs used and determinants of technical efficiency of Irish potato farmers in Plateau state, Nigeria.

\section{THEORETICAL AND CONCEPTUAL UNDERPINNING}

The study draws on the theory of production in which a farm is viewed as a cost minimising and profit maximising entity. The farm is a producing unit having the ultimate objective of profit maximization, output maximization, cost minimization, utility maximization or a combination of the four (Oluwatayo et al., 2008). Hence, employing a production function, which is a model used to specify the relationship between independent and dependent variables, the specification of the economic production function model can be represented as:

$Y=f\left(X_{1}, X_{2}, \ldots, X_{n}\right)$

Where: Y represents a firm's output and a number of inputs represented by the $X_{1}$ to $X_{n}$ purchased at given prices, $N=N_{1}, N_{2}, \ldots, N_{n}$.

Measuring production efficiency requires an understanding of farm and farmer production characteristics that influence input usage and the consequent output. Hence, the production function; $Y=$ $f(L, K)$ is used to express the relationship.

Where $f$ shows the maximum output that can be produced using combinations of inputs. $Y$ is output, $L$ and $K$ are inputs used.

The farmer maximizes profit by either increasing the quantity of $Y$ or by reducing the cost of producing $Y$. Hence, efficiency can be measured using either one of two approaches: input-oriented or output-oriented approaches (Farrell, 1957). The input-oriented approach addresses the question of how much can a production unit be proportionally reduced such that the quantities of input used to produce a given amount of output is reduced without any change in the output (Coelli et al., 1998). According to Farrell (1957), input-oriented measure of farm efficiency can be illustrated using two firms which employ two inputs of production, capital $(K)$ and labour $(L)$, to produce a single output $(Y)$, and face a production function, $Y=f(L, K)$, under the assumption of constant returns to scale. The firm seeks the level of technology that attains the least combination of inputs required to produce a unit of output. This is usually shown on an isoquant. Thus, all input combinations along the isoquant are considered technically efficient. There are technically efficient and inefficient point along the isoquant. Hence, a firm operating at a technically inefficient point will be technically inefficient since it uses inputs that could have been saved without decreasing the amount of output. Thus, all inputs need to be reduced by a percentage to achieve technically efficient production. This describes the technical efficiency (TE) of the producer. Output oriented approach of efficiency measurement, on the other hand, addresses the question of by how much can the output be increased such that the given level of input used remains unchanged, that is, without increasing the number of inputs used (Coelli et $\boldsymbol{a l}$., 1998). This approach uses production possibility curves which show the possible combination of two outputs that can be produced from a given input and level of technology. The production possibility curve represents the upper bound of production possibilities, hence, producers cannot be located above but can be located either on the curve, indicating efficient firms, or even below it, indicating inefficient firms. Hence, technical efficiency under the output-oriented approach measures the proportion by which outputs could be increased without requiring extra input. For both input and output-oriented approaches, technical efficiency lies between 0 and 1 .

In sum, technical efficiency measures how well the individual transforms inputs into a set of outputs (Wubshet, 2018; Tolno, 2016) and can be influenced by both external and internal factors (farm inputs) associated with the production environment (Bokusheva et al., 2006; Hasanthika et al., 2013). In this study, the dependent variable is the value of agricultural output harvested on the given farm. The independent variables considered to assess the technical efficiency of Irish potato farmers include various inputs such as area planted with Irish Potato, labour, fertilizers and other agrochemicals used in Irish Potato farming. The technical inputs and the management practices jointly determine the quantity and quality of output produced. Hence, the technical efficiency level of farmers is influenced by socio-economic, institutional and managerial factors which interact to affect the technical efficiency of Irish potato farming in line with Wubshet (2018), Kuwornu, et al. (2012) and, Abdulquadri \& Mohammed (2012).

\section{DATA AND METHODS}

\section{Study area}

This study was carried out in Plateau State, North-Central Nigeria. Primary data was collected using a structured questionnaire through a multi-stage sampling method. In the first stage, two local government areas (LGAs), 
Bokkos and Mangu, were randomly selected out of the five major Irish potato-producing LGAs. The second stage involved a simple random sampling of three districts each from the list of eight districts in each of the two LGAs. From the six districts, three villages each were randomly selected to make a total of 18 villages. The last stage involved a random selection of Irish potato farmers from the 18 villages in proportion to their size since an updated list of Irish potato farmers in the study area was not available. A total of 260 Irish potato farmers were randomly selected, but only 252 gave complete information which was used for data analyses. Analytical tools employed include Descriptive statistics and Stochastic frontier production function using the STATA package.

\section{Theoretical Framework and Estimation Procedure}

The stochastic frontier production function (SFPF) utilises the maximum likelihood technique due to its composite error term. Also, the technical efficiency of an individual farm is defined in terms of the ratio of observed output $\left(Y_{i}\right)$ to the corresponding frontier output $\left(Y_{i}^{*}\right)$ conditional on the level of inputs used by the firm and given the available technology (Eq. 1).

$$
\begin{aligned}
& T E_{i}=\frac{y_{i}}{y_{i}^{*}} \quad \text { i. e. } T E_{i}=\frac{f\left(x_{i} \beta_{i}\right) \exp \left(v_{i}-u_{i}\right)}{f\left(x_{i} \beta_{i}\right) \exp v_{i}} \\
& T E_{i}=\exp \left(-u_{i}\right)
\end{aligned}
$$

Where:

$T E_{i}$ technical efficiency of farmer i; $Y_{i}$ observed output from farm $\mathrm{i} ; Y_{i}^{*}$ and frontier output for farm $\mathrm{i}$.

The technical efficiency values are assumed to range between zero and one; that is as fixed given values $\left(0 \leq T E_{i} \leq 1\right)$. Thus, the technical inefficiency is equal to $1-T E$

\section{Model Specification}

A two-stage estimation procedure was used to run the stochastic frontier production function.

Stage one: The model used for this study followed that of Maina et al. (2018) and Dube et al. (2018) with a slight modification in explanatory variables. The production function is as shown Eq. 2.

$Y=f(x)$

The farmers' technical efficiency is given by the equation of the Stochastic frontier production function as in Equation 3.

$\ln Y=\beta_{0}+\beta_{1} l_{n} X_{1}+\beta_{2} l_{n} X_{2}+\beta_{3} l_{n} X_{3}+\beta_{4} l_{n} X_{4}+$
$v_{i}-u_{i}$

Where:

$Y$ Output of Irish potato (kilogram),

$X_{1}$ Farm size (hectare),

$X_{2}$ Quantity of Irish potato seed planted (kilogram),

$X_{3}$ Agrochemicals (litre),

$X_{4}$ Total labour used (man-days)

$\mathrm{v}_{i} \quad$ Stochastic error term

$u_{i}$ The inefficiency component of the error term
In Natural Logarithms

$\beta$ Coefficients to be estimated

Variance parameters: sigma-square $(\sigma 2)$ gamma $(\gamma)$ and lambda $(\lambda)$

Also, the following relationships $\sigma^{2}=\sigma_{v}^{2}+\sigma_{u}^{2}$;

$\gamma=\frac{\sigma_{v}^{2}}{\sigma^{2}} ; \lambda=\frac{\sigma_{v}^{2}}{\sigma_{u}^{2}}$

Where: $\sigma^{2}, \sigma_{u}^{2}, \sigma_{v}^{2}$ are the overall variance of the model, the variance of the random error, and variance of the technical inefficiencies respectively. The variances of the random errors, $\sigma_{v}^{2}$ and that of the technical inefficiency effects $\sigma_{u}^{2}$, and the overall variance of the model sigmasquared $\left(\sigma^{2}\right)$ are related thus: $\sigma^{2}=\sigma_{v}^{2}+\sigma_{u}^{2}$ and the ratio $\gamma=\sigma_{u}^{2} / \sigma_{v}^{2}$ measures the frontier which can be attributed to technical efficiency (Battese \& Corra, 1977) and used by Balogun \& Akinyemi (2017); Maina et al. (2018).

The Gamma $(\gamma)$ shows the explained proportion of the variation between the actual and frontier outputs, which can be attributed to underlying technical inefficiency (Battese \& Corra, 1977). Technical inefficiency of farms is measured by one minus gamma. Lambda $(\lambda)$ is expected to be $>1$. This condition indicates a good fit for the model and the correctness of the specified distribution assumptions (Tadesse \& Krishnamoorthy, 1997). (TE)

Stage Two: Determinants of Technical Efficiency

Determinants of the farmers' technical efficiency were also examined. To identify the determinants of technical efficiency, the second stage of the estimation procedure was used (Rahji, 2005). Technical efficiencies were empirically identified and regressed against the farm and farmer characteristics. Based on empirical evidence, these determinants include farmer age, farm experience, marital status, level of education, gender, household size and contact with extension agents (Rahji, 2005; Balogun \& Akinyemi, 2017).

Technical efficiency values are assumed to range between 0 and 1 as fixed given values. However, these values cannot be assumed to be normally distributed (Ekanayake, 1987; Squires \& Tobor, 1991). At this stage, it violates the assumption of ordinary least square which states that the dependent variable should be normally distributed with a mean of 0 and a constant variance suggested that the technical efficiency index estimated must be transformed into the natural logarithm of the ratio of the technical efficiency to technical inefficiency as transformed technical efficiency (TTE) (Ekanayake, 1987). This transformation makes it possible for the technical efficiency ratio to assume any value. The dependent variable for the estimating equation is as reported by Rahji (2005). The dependent variable for the estimating equation thus becomes (Eq. 4).

$T T E=\ln (T E / 1-T E)$

Where;

$T T E=$ Transformed Technical Efficiency

$T E=$ Technical Efficiency

The independent variables hypothesised to determine technical efficiency is explicitly stated as Equation 5. 
$U_{i}=\alpha_{0}+\alpha_{1} Z_{1}+\alpha_{2} Z_{2}+\alpha_{3} Z_{3}+\alpha_{4} Z_{4}+\alpha_{5} Z_{5}+$

$\alpha_{6} Z_{6}+e_{i}$

Where:

$U_{i}$ Transformed technical efficiency variable;

$Z_{1} \operatorname{Sex}($ Male $=1$, Female $=0)$;

$Z_{2}$ Access to credit $(\mathrm{Yes}=1, \mathrm{No}=0)$;

$Z_{3}$ Contact with extension agent (Yes $\left.=1, \mathrm{No}=0\right)$;

$Z_{4}$ Membership of cooperative society (member=1, Nonmember $=0$ );

$Z_{5}$ Farming Experience (years);

$Z_{6}$ Household size of farmers (number of persons in the household);

$e_{i} \quad$ Error term.

While $\alpha_{0}, \alpha_{1}, \ldots, \alpha_{6}$ are parameters to be estimated.

The $\beta$ 's and $\alpha$ 's are scalar parameters that were estimated, which reflect the elasticity of the agricultural inputs on output.

\section{RESULTS AND DISCUSSION}

Socioeconomic Characteristics of Irish Potato Farmers The description of the socioeconomic characteristics of Irish potato farmers in the study area is presented in Table 1. Males dominate Irish potato farming, and over $70 \%$ of the farmers were married with a large household size of 11 persons (Table 1). The mean age of 48 years indicates an agile workforce. This follows closely with Wassihun $\boldsymbol{e t}$ al., (2019) who also found that Irish potato farmers were mostly male and aged 47 years on the average. Over $80 \%$ of the farmers possessed some form of formal education, predominantly at the secondary level. Almost two-thirds of the farmers belonged to cooperative societies, while about $70 \%$ of farmers had no access to credit. Nearly three-quarters of farmers had contacts with extension agents, indicating they have access to information about innovations which could improve the efficiency of production. This aligns with Danso-Abeam et al. (2020) who also found majority of farmers to be members of cooperatives and having contact with extension agents. The mean farm size of about 2 hectares also shows that most farmers were small-holders.

\section{Input-Output Relationship of Irish Potato Farmers}

The results of the estimated stochastic frontier production function of Irish potato farmers are shown in Table 2. The results indicated that the variance parameter sigmasquared was significant, with a lambda $(\lambda)$ value $>1$ indicating the goodness of fit of the model. The variance ratio, $\gamma=\frac{\sigma_{v}^{2}}{\sigma^{2}}$, where $\gamma$ indicated slightly more than $50 \%$ of the variation in output was due to disparities in technical efficiency (Table 2).

The estimated coefficient of farm size was statistically significant $1 \%$ level of probability and had a positive relationship with the quantity of Irish potato produced. This indicates that an increase in the farm size by one hectare will lead to about a $38.3 \%$ increase in the kilogram of Irish potato produced. This suggests that as Irish potato farmers increase the farmland allocated to Irish potato cultivation, the output is increased. This is in accordance with Obare et al., 2010; Dube et al., 2018 who also found that increase in area planted influences output. The estimated coefficient for fertiliser was positive and significant at $5 \%$ probability level. This indicates that a $1 \%$ increase in the quantity of fertiliser applied is expected to increase the output of Irish potato production by $15.7 \%$. The coefficient for agrochemicals was positive and significant at $1 \%$ probability level, for Irish potato production, which implied that a $1 \%$ increase in the amount of agrochemicals applied would result in a $16.02 \%$ increase in Irish potato output. This suggests that to control risks posed by weeds, pests and diseases and increase output, farmers will have to efficiently and appropriately apply agrochemicals which agrees with Nyagaka et al. (2010); Akpaeti \& Frank (2021). Labour had a negative influence, significant at $10 \%$ probability level; and a coefficient indicating a $1 \%$ increase in the quantity of labour used decreases Irish potato output by $5 \%$. This may be because the sources of labour (family and "communal" labour) are readily available but usually poorly motivated, thus, leading to production inefficiencies and consequently affecting Irish potato output.

Table 1: Socioeconomic characteristics of Irish Potato farmers.

\begin{tabular}{|c|c|c|}
\hline Characteristic & Frequency & Per cent \\
\hline \multicolumn{3}{|l|}{$\overline{\text { Sex }}$} \\
\hline Female & 72 & 28.57 \\
\hline Male & 180 & 71.43 \\
\hline \multicolumn{3}{|l|}{ Age (years) } \\
\hline Mean & 48 & \\
\hline S.D. & 11.02 & \\
\hline \multicolumn{3}{|l|}{ Marital status } \\
\hline Single & 66 & 26.19 \\
\hline Married & 186 & 73.81 \\
\hline \multicolumn{3}{|l|}{ Household size } \\
\hline Mean & 11 & \\
\hline S.D. & 5.2 & \\
\hline \multicolumn{3}{|c|}{ Educational status (years) } \\
\hline No formal education & 30 & 11.90 \\
\hline $1-6$ & 76 & 30.16 \\
\hline $7-12$ & 103 & 40.87 \\
\hline Above 12 & 43 & 17.06 \\
\hline Mean & 9 & \\
\hline S.D. & 4.8 & \\
\hline \multicolumn{3}{|c|}{ Farming experience (years) } \\
\hline Mean & 18 & \\
\hline S.D. & 8 & \\
\hline \multicolumn{3}{|c|}{ Membership in cooperative } \\
\hline No & 99 & 39.29 \\
\hline Yes & 153 & 60.71 \\
\hline \multicolumn{3}{|l|}{ Access to credit } \\
\hline No & 176 & 69.84 \\
\hline Yes & 76 & 30.16 \\
\hline \multicolumn{3}{|c|}{ Contact with extension agent } \\
\hline No & 62 & 24.60 \\
\hline Yes & 190 & 75.40 \\
\hline \multicolumn{3}{|l|}{ Farm size (ha) } \\
\hline Mean & 2.32 & \\
\hline S.D. & 0.86 & \\
\hline
\end{tabular}


Table 2: Maximum likelihood Estimates Stochastic Frontier Production function.

\begin{tabular}{|c|c|c|c|c|c|}
\hline Variable & Parameter & Coefficient & Std. Err. & z-value & $\mathrm{P}>|\mathrm{z}|$ \\
\hline Constant & $\beta_{0}$ & $3.9052 * * *$ & 0.3414 & 11.44 & $\frac{11}{0.000}$ \\
\hline Farm size $\left(X_{1}\right)$ & $\beta_{1}$ & $0.3833 * * *$ & 0.0645 & 5.94 & 0.000 \\
\hline Seed $\left(X_{2}\right)$ & $\beta_{2}$ & $0.0385 \mathrm{~ns}$ & 0.0402 & 0.96 & 0.338 \\
\hline Fertilizer $\left(X_{3}\right)$ & $\beta_{3}$ & $0.1569 * *$ & 0.0747 & 2.10 & 0.036 \\
\hline Agrochemicals $\left(X_{4}\right)$ & $\beta_{4}$ & $0.1602 * * *$ & 0.0187 & 8.54 & 0.000 \\
\hline Labour $\left(X_{5}\right)$ & $\beta_{5}$ & $-0.0501 *$ & 0.0275 & -1.83 & 0.068 \\
\hline \multicolumn{6}{|l|}{ Variance Parameter } \\
\hline$\sigma^{2}$ & & 0.0431 & & & \\
\hline Lambda $(\lambda)$ & & 1.0024 & & & \\
\hline $\operatorname{Gamma}(\gamma)$ & & 0.5012 & & & \\
\hline Sample size & & 252 & & & \\
\hline
\end{tabular}

Source: Author's computation, 2019.

Note: $\mathrm{ns}, *, * *, * * *$ not significant or significant at 10,5 or $1 \%$ level.

Table 3. Elasticity of production and returns to scale estimates.

\begin{tabular}{llr}
\hline Input & Parameter & Elasticity of production \\
\hline Farm size $\left(X_{1}\right)$ & $\beta_{1}$ & 0.3833 \\
Seed $\left(X_{2}\right)$ & $\beta_{2}$ & 0.0385 \\
Fertilizer $\left(X_{3}\right)$ & $\beta_{3}$ & 0.1569 \\
Agrochemicals $\left(X_{4}\right)$ & $\beta_{4}$ & 0.1602 \\
Labour $\left(X_{5}\right)$ & $\beta_{5}$ & -0.0501 \\
Returns to scale & & 0.6888 \\
\hline
\end{tabular}

Source: Author's computation, 2019

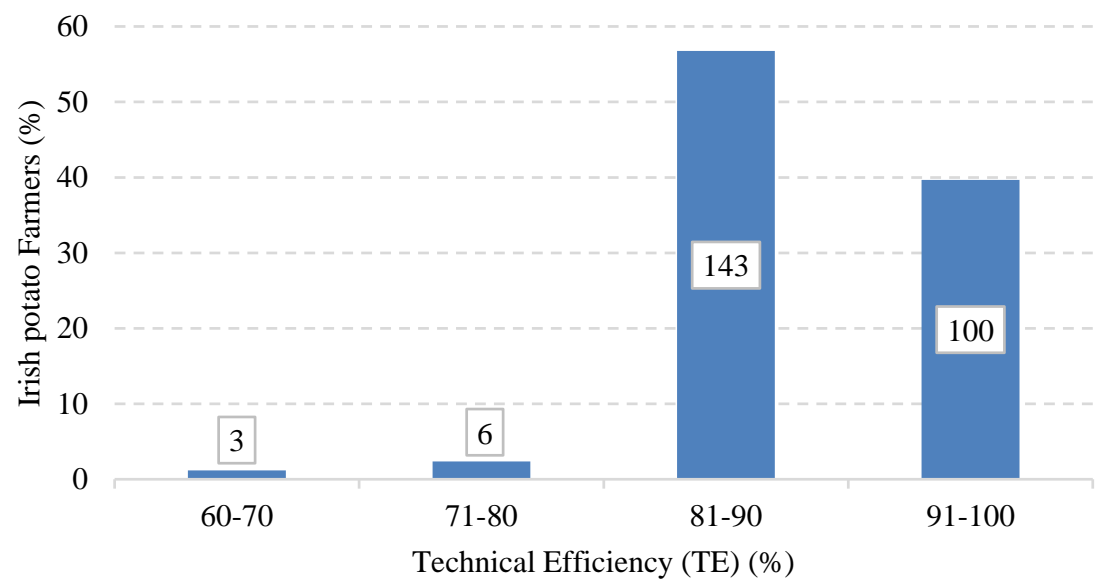

Figure 1. Distribution of Irish Potato Farmers based on their Technical Efficiency

The estimates for elasticity of production and returns to scale of Irish potato farmers are presented in Table 3. Production elasticities for inputs and returns to scale of Irish potato farmers varied. The Returns to Scale was <1 indicating Irish potato farmers were experiencing a decreasing return to scale in production, an indication that inputs used were inelastic: $1 \%$ increase in all inputs included on the production function results in $<1 \%$ increase in output of Irish potato. This indicates farmers are operating in stage II of the production region which is an economic relevance stage of production (the rational Stage) where inputs and output are efficient. At this stage, every farmer attempts to maximise output as well as minimise cost. Farmers should maintain the level of input utilisation at this stage and attempt to maximise output from a given level of inputs. The decreasing returns to scale was consistent with Nyagaka et al. (2010) and Watchmann \& Watchmann (2020).

\section{Technical Efficiency of Irish Potato Farmers in the Study Area}

The distribution of Irish potato farmers according to technical efficiency levels is depicted in Figure 1. This was derived from the analysis of the stochastic frontier production function. The technical efficiency levels indicate the majority of farmers were operating at technical efficiencies between $81-90 \%$, with fewer at 91 $100 \% ; 71-80 \%$ and $\leq 70 \%$ technical efficiencies. The least 
efficient farmer and the most efficient farmer had estimated technical efficiencies values of $65 \%$ and $97 \%$ respectively, indicating farmers were fairly efficient in production. The distribution is comparable with the results of Dube et al. (2018) though farther from Wassihun et al., (2019) who found least efficient farmers to have estimated technical efficiency values of $46 \%$ on Irish potato production. The mean technical efficiency score implies that the average farmer was able to obtain $89 \%$ of the potential output at the given input level and technology. On average, farmers were relatively efficient, but some output was lost due to technical inefficiency which could be due to farming systems or to inefficiency among the farmers, or both. Although not a single farmer appears as fully technically efficient, the result indicates that on average, the output level can be increased without necessarily employing additional resources. An average farmer in the study area could reduce cost and attain the technical efficiency level of its most efficient counterpart. The least efficient farmer could also reduce cost and attain the technical efficiency level of the most efficient farmer through adopting practices and technology used by the most efficient farmer. The results of this study agree with Nyagaka et al. (2010) and Akpaeti \& Frank (2021) on the technical efficiency of smallholder farmers.

\section{Determinants of Technical Efficiency of Irish Potato Farmers}

Table 4 reveals the regression estimates for the determinants of technical efficiency of Irish potato farming in the study area. Most of the estimated regression coefficients were positive, and significant, indicating their relative effect in increasing technical efficiency. The coefficient of multiple determinations $\left(\mathrm{R}^{2}\right)$ indicated independent variables explained variation in technical efficiency; the remaining amount was attributed to uncaptured variables in the model. The F-Statistics was significant, indicating the joint effect of variables included in the model was able to determine technical efficiency. The coefficient of Sex was positive, and significant at $1 \%$, indicating that being a male farmer improves technical efficiency. The majority of the farmers were male. This suggests that male farmers were more likely to be technically efficient than female farmers. Being male farmer increased technical efficiency by 3.3816 magnitudes compared to being a female farmer. This could be explained by the fact that the male farmers are decision-makers, had access to land, labour supply and other production resources due to cultural prejudice. This result is consistent with Danso-Abeam et al. (2020) Similarly, the coefficient of extension contact was positive and significantly influenced technical efficiency at $1 \%$ level. Farmers who have contacts with extension officers would increase technical efficiency as such farmers gain better knowledge on input use, access modern agricultural technology, obtain information on proper agronomic practices relating to land preparation, planting, weeding, fertiliser application, pests and diseases control, improving farmer technical efficiency (Dube et al., 2018). Membership in cooperatives had a positive and significant influence on technical efficiency at $1 \%$ level. This indicates that farmers who are members of cooperatives are more likely to improve their technical efficiency because they tend to enjoy benefits such as access to relevant information on-farm management practices, introduction of new technologies, and financial assistance (Nyagaka et al., 2009; Akpaeti \& Frank, 2021). The farming experience was positive and significant at $5 \%$ level, indicating that a year increase in farming experience would increase technical efficiency indicating by $5.79 \%$ (Table 1). Hence, the more years farming, the better the technical efficiency of the farmer. Farmers who have more years of experience would be more likely to have good managerial abilities, improved technical skills, and broader networking with other farmers on best agronomic practices and efficient use of inputs (Otitolaiye $\boldsymbol{e t}$ al., (2014). Household size was negatively and significantly influenced technical efficiency at $1 \%$ level. This implies that increased household size would reduce technical efficiency. This may be due to a greater cash constraint leaving the household with little cash to purchase production inputs and new technologies (Dube $\boldsymbol{e t}$ al., 2018; Danso-Abeam et al., 2020). Finally, it was noted that none of the Irish potato farmers operated on the production frontier (efficient level), indicating there is room for improvement. Irish potato farmers operate at a rational state of production.

Table 4. Estimated factors influencing technical efficiency of Irish potato farmers.

\begin{tabular}{llllll}
\hline Variable & Parameter & Coefficient & Std. Err. & t- value $P>|t|$ \\
\hline Constant & $\alpha_{0}$ & $4.7353^{* * *}$ & 0.5828 & 8.13 & 0.000 \\
Sex (Male $=1$, Female $=0)$ & $\alpha_{1}$ & $3.3816^{* * *}$ & 0.5276 & 6.41 & 0.000 \\
Access to credit $(Y e s=1, \mathrm{No}=0)$ & $\alpha_{2}$ & $0.5346 \mathrm{~ns}$ & 0.3888 & 1.37 & 0.170 \\
Extension contact $(Y e s=1, \mathrm{No}=0)$ & $\alpha_{3}$ & $0.8941^{* * *}$ & 0.1121 & 7.98 & 0.000 \\
Membership in cooperative $(\mathrm{Yes}=1, \mathrm{No}=0)$ & $\alpha_{4}$ & $1.6831^{* * *}$ & 0.4434 & 3.80 & 0.000 \\
Farming experience (Years) & $\alpha_{5}$ & $0.0579^{* *}$ & 0.0273 & 2.12 & 0.035 \\
Household size (number) & $\alpha_{6}$ & $-0.1449 * * *$ & 0.0391 & -3.70 & 0.000
\end{tabular}

$\mathrm{R}^{2}=0.51$

Adj $R^{2}=0.50$

$\mathrm{F}-\mathrm{Stat}=42.37 * * *$

Sample size $=252$

Source: Author's computation, 2019, ns, ${ }^{* *}, * * *$ not significant or significant at 5 or $1 \%$ levels, respectively. 


\section{CONCLUSIONS AND RECOMMENDATIONS}

This study set out to measure the technical efficiency of Irish potato farmers in Nigeria's Plateau state and identify the factors that cause variation in the technical efficiency of farmers in the study area. None of the sampled Irish potato farmers operated on the production frontier (efficient level), indicating a gap in efficiency and room for its improvement. The farmers were operating below the production frontier due to technical inefficiency, which is attributed to farming systems or due to the inefficiency among the sampled farmers, or both. The study established that Irish potato farmers operate at the rational state of production. In contrast, socioeconomic factors of gender, extension contact, membership in cooperative society and farming experience were positive determinants of farmers' technical efficiency, while household size was a negative determinant/was negative. Thus, encouraging contact between farmers and extension workers will enhance their level of efficiency in the production of Irish potatoes. Since farming experience also improves the level of efficiency, new entrants into Irish potato farming should consider either hiring experienced Irish potato farmers or understudying them for efficient production. Membership of cooperative societies should also be encouraged among Irish potato farmers to attain an optimal level of efficiency. It is also recommended that birth control measures are recommended for Irish potato farming households to bring about the desired efficiency level in production. Finally, since it was established that being a male farmer increases efficiency of Irish potato production compared to being a female farmer, it is recommended that further research should be done to identify factors that can increase the efficiency of Irish potato production among female farmers.

\section{REFERENCES}

ABDULQUADRI, A. F., \& MOHAMMED, B. T. (2012). The Role of Agricultural Cooperatives in Agricultural Mechanization in Nigeria. World Journal of Agricultural Sciences, 8(5), 537-539.

AKPAETI, A. J., \& FRANK, N. N. (2021). Technical efficiency of cassava cooperative farmers in SouthSouth Nigeria: A comparative analysis. Nigerian Agricultural Journal, 52(2), 8-14.

AMADI, C. O., GHISLAIN, M., KHAYA, S. S., DABELS, V., NNADI, N. E. \& AMADI, G. (2021). Prospects of mitigating late blight disease of potato in Nigeria through deployment of Triple R (3R) stacked gene transgenic varieties. Nigerian Agricultural Journal, 52(2), 108-114.

BALOGUN, O. L., \& AKINYEMI, B. E. (2017). Land fragmentation effects on technical efficiency of cassava farmers in the South-West geopolitical zone. Cogent Social Sciences, 3(1), 1387983. 1-10. https://doi.org/10.1080/23311886.2017.1387983

BATTESE, G. E., \& CORRA, G. S. (1977). Estimation of a production frontier model: with application to the pastoral zone of eastern Australia. Australian Journal of Agricultural Economics, 21(3), 167-179. https://doi.org/10.1111/j.1467-8489.1977.tb00204.x

BATTESE, G. E., \& TESSEMA, G. A. (1993). Estimation of stochastic frontier production functions with timevarying parameters and technical efficiencies using panel data from Indian villages. Agricultural Economics, 9(4), 313-333. https://doi.org/10.1016/0169-5150(93)90020-D

BOKUSHEVA, R., \& HOCKMANN, H. (2006). Production risk and technical inefficiency in Russian agriculture. European Review of Agricultural Economics, 33(1), 93-118. https://doi.org/10.1093/erae/jbi036

COELLI, T. (1998). A multi-stage methodology for the solution of orientated DEA models. Operations Research Letters, 23(3-5), 143-149. https://doi.org/10.1016/S0167-6377(98)00036-4

DANSO-ABBEAM, G., BAIYEGUNHI, L. J. S., \& OJO, T. O. (2020). Gender differentials in technical efficiency of Ghanaian cocoa farms. Heliyon, 6(5), 111. https://doi.org/10.1016/j.heliyon.2020.e04012

DIMLONG, S. Y. (2012). Best practices on potato (Solanum tubersum L) production and storage. German Agency for International Cooperation GIZ. Abuja Nigeria. pp18.

DUBE, A. K., OZKAN, B., AYELE, A., IDAHE, D., \& ALIYE, A. (2018). Technical efficiency and profitability of potato production by smallholder farmers: The case of Dinsho district , Bale Zone of Ethiopia. Journal of Development and Agricultural Economics, 10(7), 225-235. https://doi.org/10.5897/JDAE2017.0890

EKANAYAKE, S. A. B. (1987). Location specificity, seller-type and productive efficiency: A study of the Mahavel project in Sri Lanka. Journal of Development Studies, 23(4), 509-521. https://doi.org/10.1080/00220388708422046

FARRELL, M. J. (1957). The measurement of productive efficiency. Journal of the Royal Statistical Society: Series A (General), 120(3), 253-281. https://doi.org/10.2307/2343100

FAOSTAT. Food and Agricultural Organization Statistical Database (2016). http://faostat3.fao.org/download/FB/CC/E

FAOSTAT. Food and Agricultural Organization Statistical Database (2019a). http://www.potatopro.com/world/potato-statistics

FAOSTAT. Food and Agricultural Organization Statistical Database (2019b). https://www.fao.org/faostat/en/\#data/CC

JWANYA, B. A., DAWANG, N. C., ZARMAI, D. C., \& MASHAT, I. M. (2014). Economic analysis of irrigated Irish Potato production in Plateau State, Nigeria. Developing Country Studies, 4(12):80-86. ISSN 2224-607X. https://www.iiste.org/Journals/index.php/DCS/article/ view/13496

KUWORNU, J. K., AMEGASHIE, D. P., \& WUSSAH, C. E. (2012). Productivity and Resource Use Efficiency in Tomato and Watermelon Farms: Evidence from Ghana. Developing Country Studies, 2(2),

23-37. 
https://www.iiste.org/Journals/index.php/DCS/article/ view/1015

MAINA, F., MBURU J., GITAU G., VANLEEUWEN J., \& NEGUSSE, Y. (2018). Economic efficiency of milk production among small- scale dairy farmers in Mukurweini, Nyeri County, Kenya. Journal of Development and Agricultural Economics, 10(5),152158. https://doi.org/10.5897/JDAE2017.0915

MUHAMMAD, A., GINDI, A. A., GONA, A., \& KAKA, Y. (2016). Partial economic analysis of Irish potato production under Kebbi State agroecological conditions. International Journal of Life Sciences Scientific Research, 2(2): 183-190. ISSN: 2455-1716. https://iijls.com/currentissue/IJLSSR-1074-102015.pdf

NYAGAKA, D. O., OBARE, G. A., \& NGUYO, W. (2009). Economic efficiency of small-holder Irish potato producers in Kenya: A case of Nyandarua North District [Conference session]. The International Conference of Economists, 16-22 August 2009, Beijing, China. doi: 10.13140/2.1.3409.4089

NYAGAKA, D. O., OBARE, G. A., OMITI, J. M., \& NGUYO, W. (2010). Technical efficiency in resource use: Evidence from smallholder Irish potato farmers in Nyandarua North District, Kenya. African Journal of Agricultural Research, 5(11), 1179-1186. https://doi.org/10.5897/AJAR09.296

OBARE, G. A., NYAGAKA, D. O., NGUYO, W., MWAKUBO, S. M. (2010). Are Keyan smallholders allocatively efficient? Evidence from Irish potato producers in Nyandarua North District. Journal of Development and Agricultural Economics, 2(3), 7885. ISSN 2006-9774. https://academicjournals.org/journal/JDAE/articleabstract/0B1250C4382

OKONKWO, J. C., AMADI, C. O., \& NWOSU, K. I. (2009). Potato production, storage, processing and utilization in Nigeria. National Root Crops Research Institute, Umudike, Nigeria.

OLUWATAYO, I. B., SEKUMADE, A. B., \& ADESOJI, S. A. (2008). Resource use efficiency of maize farmers in rural Nigeria: Evidence from Ekiti State. World Journal of Agricultural Sciences,4(1), 91-99. http://www.idosi.org/wjas/wjas4(1)/17.pdf

OTITOLAIYE, J. O., OHAJIANYA, D. O., SALIU, O. J., IBITOYE, S. J., IBEKWE, U. C., \& ANAETO, F. C. (2014). Technical efficiency of sweet potato farmers in Okene Local Government area of Kogi State, Nigeria. Asian Journal of Agricultural Extension, Economics and Sociology, 3(2), 108-117. doi: 0.9734/AJAEES/2014/6945

PANWAL E. F. (2018). Resource Use and Productivity Among Rain-Fed and Irrigated Irish Potato Producers in Plateau State, Nigeria. Journal of Agriculture and Sustainability, 11(1), 1-10. https://www.infinitypress.info/index.php/jas/article/vi $\underline{\text { ew/1616 }}$

RAHJ, M. A. Y. (2005). Determinants of efficiency differentials in lowland rice production systems in Niger State, Nigeria. Ibadan Journal of Agricultural Research, 1(1), 7-17. http://ijar.org.ng/wpcontent/uploads/2019/06/3-determinants-of- efficiency-differentials-in-lowlands-rice-productionsystems.pdf

SANUSI, M. M., \& BABATUNDE, D. A. (2017). Analysis of potato consumption among households in Odeda local government area, Ogun State, Nigeria. Journal of Agriculture, 2, 89-99. https://doi.org/10.1515/ats-2017-0010

SCHULTE-GELDERMANN, E. (2013). Tackling low potato yields in Eastern Africa: An overview of constraints and potential strategies. In: $G$. Woldegiorgis, S. Schulz, and B. Berihun (eds.). Seed potato tuber production and dissemination, experiences, challenges and prospect: Proceedings. National Workshop on Seed Potato Tuber Production and Dissemination. Bahir Dar (Ethiopia). Ethiopian Institute of Agricultural Research, Amhara Regional Agricultural Research Institute; International Potato Center, 72-80. ISBN 978-99944-53-87-x. https://hdl.handle.net/10568/57049

SHER, A., ZEESHAN, M., GILANI, S., MUSTAFA, G., \& MUSHTAQ, K. (2016). Investigation of the Factors Affecting the Potato Production with Special Reference to Farmers Entrepreneurial Level in Punjab, Pakistan. Journal of Agriculture \& Basic Sciences, 1(2), 30-37.

SQUIRES, D. \& TOBOR, S. (1991). Technical efficiency and future production gains in Indonesian agriculture. The Developing Economies, 29(3), 258-270. https://doi.org/10.1111/j.1746-1049.1991.tb00211.x

TADESSE, B., \& KRISHNAMOORTHY, S. (1997). Technical efficiency in paddy farms of Tamil, Nadu: An analysis based on farm size and ecological zone. Agricultural Economics, 16(3), 185-192. https://doi.org/10.1111/j.1574-0862.1997.tb00453.x

TOLNO, E., KOBAYASHI, H., ICHIZEN, M., ESHAM, M., \& BALDE, B. S. (2016). Potato production and supply by smallholder farmers in Guinea: an economic analysis. Asian Journal of Agricultural Extension, Economics \& Sociology, 8(3), 1-16. doi:10.9734/AJAEES/2016/21726

UMOH, G. S. (2006). Resource use efficiency in urban farming: An application of stochastic frontier production function. International Journal of Agriculture and Biology, 8(1), 38-44.

WASSIHUN, A. N., KOYE, T. D., \& KOYE, A. D. (2019). Analysis of technical efficiency of potato (Solanum tuberosum L.) production in Chilga District, Amhara National Regional State, Ethiopia. Economic Structures 8(34). https://doi.org/10.1186/s40008-0190166-y

WATCHMANN, B., \& WATCHMANN, R. (2020). Non parametric estimation of primary care production function in urban Brazil. Health Economic Review, 10(37). https://doi.org/10.1186/s13561-020-00294-9

WUBSHET, S. G., WOLD, J. P., AFSETH, N. K., BÖCKER, U., LINDBERG, D., IHUNEGBO, F. N., \& MÅGE, I. (2018). Feed-forward prediction of product qualities in enzymatic protein hydrolysis of poultry by-products: a spectroscopic approach. Food and Bioprocess Technology, 11, 2032-2043. https://doi.org/10.1007/s11947-018-2161-y 
WUYEP, S. Z., ZEMBA, A. A., \& JAHKNWA, C. J. (2013). Effects of precipitation effectiveness on the yield of Irish potato (Solanum tuberosum ) in Josplateau, Nigeria. International Journal of Research in Applied, Natural and Social Sciences, 1(5), 27-32. ISSN 2321-8851

ZEMBA, B. A. A., WUYEP, S. Z., ADEBAYO, A. A., \& JAHKNWA, C. J. (2013). Growth and yield response of Irish potato (Solanum tuberosum) to the climate in Jos-South, Plateau State, Nigeria. Global Journal of Human Social Science Geography, Geo-sciences, Environmental Disaster Management, 13(5), 13-18. ISSN:

0975-587X

https://globaljournals.org/GJHSS Volume13/2-

Growth-and-Yield-Response-of-Irish-Potato.pdf 